Disponível em

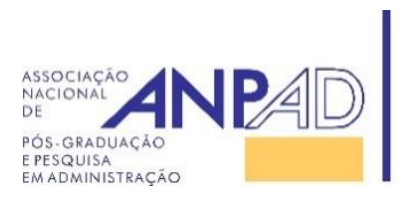

http://www.anpad.org.br/rac

RAC, Rio de Janeiro, v. 22, n. 2, art. 4, pp. 226-248, março/abril, 2018,

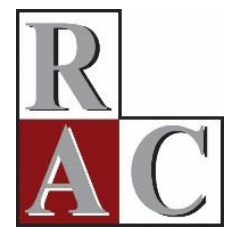

\title{
Effects of Entrepreneurial Characteristics and University Environment on Entrepreneurial Intention
}

\author{
Gustavo Hermínio Salati Marcondes de Moraes $^{1}$ \\ Edson Sadao Iizuka ${ }^{2}$
}

Matheus Pedro ${ }^{1}$

Universidade Estadual de Campinas, Faculdade de Ciencias Aplicadas, Limeira, SP, Brasil ${ }^{1}$ Centro Universitário da Fundação Educacional Inaciana "Padre Sabóia de Medeiros", São Paulo, SP, Brasil²

Artigo recebido em 25.04.2017. Última versão recebida em 09.11.2017. Aprovado em 13.11.2017. 


\title{
Resumo
}

O estudo teve como objetivo investigar os efeitos das características empreendedoras e do ambiente universitário na intenção empreendedora do estudante universitário. Foi desenvolvido e validado um modelo que considera o ambiente universitário, a autoeficácia e assumir riscos como influenciadores diretos da intenção empreendedora, e as características empreendedoras como influenciadoras da autoeficácia. A metodologia empregada foi quantitativa e os dados foram analisados por meio de Modelos de Equações Estruturais com a técnica de Mínimos Quadrados Parciais (PLS-SEM). A amostra utilizada foi composta por 287 estudantes universitários do último ano dos cursos de graduação da Universidade Estadual de Campinas (Unicamp). Os resultados indicam que a intenção empreendedora dos estudantes é influenciada pelo ambiente universitário, pela atitude em relação a assumir riscos e pela autoeficácia. A autoeficácia, por sua vez, é influenciada pelas características de planejador, liderança e inovador dos estudantes. A pesquisa colabora com reflexões complementares aos estudos sobre empreendedorismo, apresentando um modelo para avaliação das características empreendedoras dos estudantes e do contexto empreendedor das instituições de ensino, e comprovando que existe uma relação positiva entre o contexto e a educação empreendedora com a intenção empreendedora dos estudantes.

Palavras-chave: intenção empreendedora; ambiente universitário; perfil empreendedor.

\begin{abstract}
This study aimed to investigate the effects of entrepreneurial and university environment characteristics on the entrepreneurial intention of the undergraduate student. We developed a model that considers the university environment, self-efficacy, and risk-taking as direct influencers of entrepreneurial intention, and entrepreneurial characteristics as influencers of self-efficacy. We employed quantitative methodology and data were analyzed by Structural Equation Models using the Partial Least Squares (PLS-SEM) technique. The sample consisted of 287 students in the final year of undergraduate programs at the State University of Campinas (Unicamp). The results indicate that the entrepreneurial intention of students is influenced by the university environment and the attitude toward risk-taking and self-efficacy. Self-efficacy, in turn, is influenced by student characteristics regarding planning, leadership, and innovation. The research corroborates with complementary reflections on entrepreneurship studies, showing a model for evaluation of entrepreneurial characteristics of students and of the entrepreneurial context in educational institutions, and proving that there is a positive relationship between the context, entrepreneurial education and entrepreneurial intention of the students.
\end{abstract}

Key words: entrepreneurial intention; university environment; entrepreneurial profile. 


\section{Introduction}

Students' interest in entrepreneurship as a career option is increasing and this growing interest has been emphasized by many researchers (Brenner, Pringle, \& Greenhaus, 1991; Fleming, 1994; Kolvereid, 1996; Zellweger, Sieger, \& Halter, 2011). This interest is reflected in the increase in research on entrepreneurial intention and its antecedents, through the potential of understanding entrepreneurial behavior (Fayolle \& Gailly, 2015).

Some contextual factors impact the entrepreneurial intention of university students (Turker \& Selcuk, 2009). The study by Turker and Selcuk (2009) present a model in which entrepreneurial intention is taken as a function of educational, relational, and structural supports. In this way, Saeed, Yousafzai, Yani-De-Soriano, and Muffatto (2015) proposed an integrative framework with three dimensions of university support (perceived educational support, concept development support, and business development support), which influences students' entrepreneurial self-efficacy, and this entrepreneurial self-efficacy together with individual motivations directly influences the intention to start a business. Souitaris, Zerbinati, and Al-laham (2007) proved that entrepreneurship programs increase a student's intention to start a business.

Thus, the university environment has a major impact on the attitudes of students in relation to entrepreneurship (Autio, Keeley, Klofsten, \& Ulfstedt, 1997; Fayolle \& Liñán, 2014; Johannisson, 1991; Tkachev \& Kolvereid, 1999). As an example, some research results show that the number of elective management disciplines that students from other programs (such as engineering and economics) attend during their undergraduate years has a positive effect on these students' entrepreneurial intentions (Chen, Greene, \& Crick, 1998; Fayolle \& Liñán, 2014).

Entrepreneurship education can be classified into three categories (Jamieson, 1984). The first considers the education about enterprise that deals with theoretical aspects of entrepreneurship. The second one is education for enterprise and refers to practical knowledge and skills required to set-up and run a business. The third one is education in enterprise, which deals with training students in areas such as management development, marketing, product development, among others (Jamieson, 1984).

The present study seeks to explore the construct of the university environment instead of entrepreneurship courses, as an influencer of entrepreneurial intention. The university environment was adopted to conceptualize learning in the different spaces of teaching, research, and outreach (for example: events, workshops, lectures, participation in student organizations) that students have at their disposal in a higher education institution (Fayolle \& Liñán, 2014). In Jamieson's (1984) classification, the university environment can be considered to offer entrepreneurship education in three categories: education about enterprise; education for enterprise; and education in enterprise.

A second point of interest of this study is self-efficacy. Many studies have shown that self-efficacy is a predictor of entrepreneurial intention (Chen et al., 1998; Piperopoulos \& Dimov, 2015; Pittaway, Rodriguez-Falcon, Aiyegbayo, \& King, 2010; Robinson \& Sexton, 1994; Zellweger et al., 2011). These authors also explore the role of entrepreneurial education, with entrepreneurship courses, in entrepreneurial intention.

Self-efficacy may be described as individuals' conscious beliefs in their abilities and skills (Bandura, 1986). The relationship of self-efficacy and entrepreneurial intention has already been explored by researchers. The greater the belief that the individual has in their abilities, the greater the entrepreneurial intention (Koh, 1996; Krueger \& Brazeal, 1994; Luthje \& Franke, 2003; Pittaway et al., 2010).

A risk-taking construct was also considered as a direct predictor of entrepreneurial intention, since it was considered to be an important element, but could not be directly related to self-efficacy. Zhang, Wang, and Owen (2015) emphasize that risk-taking is a central part of entrepreneurial intention, and that entrepreneurial activities are risky endeavors by nature. Douglas and Shepherd (2002) have shown that a positive attitude toward risk is associated with a higher entrepreneurial intention. 
In this context, this study aimed to understand the effects of university environment characteristics, self-efficacy, and risk-taking on the entrepreneurial intention of undergraduate student. Thus, the question of this research is: How do university environment characteristics, self-efficacy, and risk-taking influence the entrepreneurial intention of undergraduate students?

We intended to test factors related to the entrepreneurial profile as indirect influencers of entrepreneurial intention and direct influencers of self-efficacy, as well as test whether the assessment of the university environment in terms of entrepreneurship has a positive effect on the entrepreneurial intentions of students, and finally the effect of risk-taking on entrepreneurial intentions.

Research in the area of entrepreneurship has already established that some entrepreneurial characteristics influence entrepreneurial intention. However, few studies have investigated the university environment as a context for entrepreneurship (Bignotti \& Le Roux, 2016; Piperopoulos \& Dimov, 2015).

This research was conducted at University of Campinas (Unicamp). The choice of Brazilian students is due to the fact that the research was conducted in a resource constrained reality that might, perhaps, provide different results from previous studies in developed countries. Another interesting point is that Unicamp has a very large number of student organizations, with more than 50 spread across different campuses, which can stimulate the university environment in terms of entrepreneurship.

Unicamp is among the 12 best teaching and research institution of the BRICS countries, according to the QS international ranking (Quacquarelli Symonds, 2016). The institution appears as the second best in Brazil and the $191^{\text {st }}$ best in the world according to the same ranking. In the international ranking by the British publication, Times Higher Education, of the World University Ranking 2018, the university is at the 401-500 level in the world and first place in Brazil (Times Higher Education, 2017). The university has higher entrepreneurship outputs when compared with other universities from emerging countries. Unicamp's internal entrepreneurial university pathways have a positive effect on students' start-up actions (Guerrero, Urbano, \& Gajón, 2014).

Final-year students of engineering and business undergraduate programs at Unicamp were chosen to participate in the research. According to data from Agência Inova Unicamp in a survey done with alumni since 1968, 537 entrepreneurs were mapped. The knowledge area at Unicamp that generates more entrepreneurs is engineering (38\%) (Izique, 2016). Thus, the choice of students from the engineering program is based on the fact that it is the area with the largest number of entrepreneurs, in addition to being one of the university's most traditional programs. Students from the business program were chosen because it is the program with more disciplines involving entrepreneurship and a greater emphasis on entrepreneurial activity.

Brazil is an interesting place to conduct this research, as Brazilians have a high entrepreneurial intention and demand for entrepreneurship education at universities (Lima, Lopes, Nassif, \& Silva, 2015). The authors have shown that these numbers are considerably higher compared with international results. The Brazilian university environments' features are important in establishing the boundaries of this research. However, this study can improve the current general theory once these features are considered.

Few studies have focused on entrepreneurial intentions of specific samples, such as a specific reality of an emerging country (Brazilian) university, with specific entrepreneurial characteristics (Bignotti \& Le Roux, 2016; Liñán \& Fayolle, 2015).

\section{Theoretical Reference}

\section{Entrepreneurial profile}

The entrepreneurial profile has been a focus of research seeking to identify common characteristics and competencies of the entrepreneurs studied and in the literature on the subject. Since 
the seminal work of McClelland (1961), several studies have been carried out in order to understand the characteristics and the profile of entrepreneurs. Research presented by Gupta and Fernandez (2009) analyzed 92 characteristics including attributes of human behavior. Turan and Kara (2007) analyzed aspects such as religion, politics, networks, ideologies, besides personal characteristics. There are also more specific investigations from a gender aspect such as that by Sarri and Trihopoulou (2005).

More recently, seeking to measure entrepreneurship, instruments to interpret the very entrepreneurial profile and measurements of entrepreneurial intention were observed, that is, the intention to open a new business (Gatewood, Shaver, Powers, \& Gartner, 2002; Peterman \& Kennedy, 2003; Segal, Borgia, \& Schoenfeld, 2005; Wang \& Wong, 2004) and measurements focusing on issues of financial performance (Hindle \& Cutting, 2002).

We seek to mirror other similar research, such as that by Schmidt and Bohnenberger (2009) who studied the conceptual basis of the entrepreneurial profile and validated a business profile measurement tool. Rocha and Freitas (2014) observed considerable changes in a sample that participated in training, especially in the dimensions of risk, self-realization, innovation, and planning.

In this study, we attempted to use the conceptual base built and validated regarding the entrepreneurial profile and entrepreneurial intention, and extend the model with the conceptual basis of a university environment. From definitions in the existing literature, common attitudinal characteristics were extracted to support the study hypotheses.

Thus, the proposed characteristics to identify the entrepreneurial profile include: self-efficacy, sociability, planning, leadership, innovation, and risk-taking. Definitions of the constructs are presented in Table 1.

Table 1

Attitudinal Characteristics of the Entrepreneurial Profile of this Study

\begin{tabular}{lll}
\hline $\begin{array}{l}\text { Attitudinal } \\
\text { characteristics }\end{array}$ & Description & Conceptual basis \\
\hline Self-efficacy & $\begin{array}{l}\text { People who have ability to achieve intended } \\
\text { results. }\end{array}$ & $\begin{array}{l}\text { Carland, Hoy e Carland (1988); Chen, } \\
\text { Greene and Crick (1998); Markman and } \\
\text { Baron (2003); Schmidt and Bohnenberger } \\
\text { (2009); Rocha and Freitas (2014). }\end{array}$ \\
Sociability & $\begin{array}{l}\text { Degree of social network use for professional } \\
\text { activity support. }\end{array}$ & $\begin{array}{l}\text { Markman and Baron (2003); Schmidt and } \\
\text { Bohnenberger (2009); Rocha and Freitas } \\
\text { (2014). }\end{array}$ \\
Planning & $\begin{array}{l}\text { People who organize the activities required to } \\
\text { achieve a desired goal. }\end{array}$ & $\begin{array}{l}\text { Filion (2000); Schmidt and Bohnenberger } \\
\text { (2009); Rocha and Freitas (2014). }\end{array}$ \\
Leadership & $\begin{array}{l}\text { People who, from their own goals, influence } \\
\text { others to voluntarily adopt this goal. }\end{array}$ & $\begin{array}{l}\text { Filion (2000); Schmidt and Bohnenberger } \\
\text { (2009); Rocha and Freitas (2014). }\end{array}$ \\
Innovation & $\begin{array}{l}\text { People who apply new ideas, devices, or } \\
\text { methods. }\end{array}$ & $\begin{array}{l}\text { Carland } \text { et al. (1988); Degen (1989); Filion } \\
\text { (2000); Schmidt and Bohnenberger (2009); } \\
\text { Rocha and Freitas (2014). }\end{array}$ \\
& $\begin{array}{l}\text { People who, in the face of a personal project, } \\
\text { list and analyze the variables that can } \text { et al. (1988); Drucker (1986); } \\
\text { influence its result, and from this decide the } \\
\text { project continuity. }\end{array}$ & $\begin{array}{l}\text { Schmidt and Bohnenberger (2009); Rocha } \\
\text { and Freitas (2014). }\end{array}$ \\
\hline
\end{tabular}




\section{University environment}

Increasingly, entrepreneurship education has become an important issue for university administrators, program coordinators, government, and researchers (Kuratko, 2005). One of the reasons for the growing interest in education for entrepreneurship is the impact of entrepreneurship on economics and job growth (Audretsch, Grilo, \& Thurik, 2011).

Several studies have indicated that business education increases the positive perception about entrepreneurship, such as attitudes and intentions (Fayolle \& Liñán, 2014; Iizuka \& Moraes, 2014; Kolvereid \& Moen, 1997; Liñán, Rodríguez-Cohard, \& Rueda-Cantuche, 2011; Tkachev \& Kolvereid, 1999). This importance is due to the fact that these perceptions precede entrepreneurial activities, such as past entrepreneurial exposure, context and institutions, and starting a new business (Fayolle \& Liñán, 2014). That is, activities that occur inside and sometimes outside the classroom.

In Brazil, the universities should respect the inseparability of teaching, research, and outreach, according to the Federal Constitution of 1988. However, researchers have directed their efforts to teaching-related aspects, that is, analysis of the pedagogic project, criticisms and proposals focused on curriculum, assessments about the techniques used, and case studies of experiences developed in a given educational institution (Godoy \& Antonello, 2009).

On the other hand, it is acknowledged that the university environment consists of teaching, research, and outreach activities. In the field of research, undergraduate research projects, capstone course papers, and timely research that occur in different disciplines may focus on the theme of entrepreneurship (Fayolle \& Liñán, 2014; Iizuka \& Moraes, 2014).

Outreach activities, in turn, include several activities such as lectures, events, workshops, business incubators, junior companies, academic administrations and centers, college societies associations, and other student organizations; that is, students have the opportunity to put entrepreneurship into practice.

Some aspects of entrepreneurship can be taught in a traditional lecture lesson, such as theoretical and cultural aspects. However, skills and competencies such as creativity, innovation, proactivity, and propensity to risk are aspects that have not yet been properly backed up by appropriate teaching methods. A pedagogical line more focused on practice may be more suitable for the teaching of entrepreneurship (Honig, 2004; Lautenschläger \& Haase, 2011; Peterson \& Limbu, 2010; Ruskovaara, Pihkala, Rytkölä, \& Seikkula-Leino, 2010).

Boyles (2012) emphasizes that entrepreneurial training has a multidisciplinary feature, and to achieve different goals it is necessary to trace a teaching plan to adapt the pedagogical methodology to the context of the expected learning. In this perspective, different options of methods, techniques, and resources are found in the literature as a way to promote the teaching-learning process of entrepreneurial training (Degen, 2009; Honig, 2004; Ilander, 2010; Knotts, 2011; Kuratko, 2005; Schmidt, Soper, \& Facca, 2012).

Some teaching-learning pedagogical options are: lectures, recommended readings, case studies, visits to companies, brainstorming, simulations, and projects developed in groups (Henrique \& Cunha, 2008). Other options are: development of business plans, interviews with entrepreneurs, and use of movies (Kuratko, 2005). This variety of pedagogical options is a result of the specificity of entrepreneurial training, which requires educational models that allow students to develop entrepreneurial skills and techniques through practical experience during their learning (Giovanela, Gouveia, Frâncio, \& Dalfano, 2010; Knotts, 2011; Ruskovaara et al., 2010).

The authors of this study believe that part of the teaching-learning options are present, not only in education, but also in research and outreach. Thus, for the purposes of this research, the nomenclature university environment was adopted to conceptualize different spaces in teaching, research, and outreach that students have at their disposal in a higher education institution. It is understood that 
students are developing their entrepreneur profile when they are executing all kinds of activity inside the university environment, as presented in the research model (Fayolle \& Liñán, 2014).

The study is also based on the concept of the theory of planned behavior (Ajzen, 1991) and its antecedents (Ajzen \& Fishbein, 1980). In the study's model, the university environment influences entrepreneurial intention. The intention-based models have already been tested in different situations related to entrepreneurship confirming the applicability of the concept in different settings (Autio, Keeley, Klofsten, Parker, \& Hay, 2001; Kolvereid, 1996; Krueger, 1993; Liñán \& Chen, 2009).

\section{Conceptual Model of Research and Study Hypotheses}

From the literature review and formulation of the hypotheses, a model was elaborated to meet the research purpose (Figure 1), which aims to understand the effects of university environment characteristics, self-efficacy, and risk-taking on the entrepreneurial intention of undergraduate students. Visual representation facilitates understanding of the theoretical model proposed (Whetten, 1989).

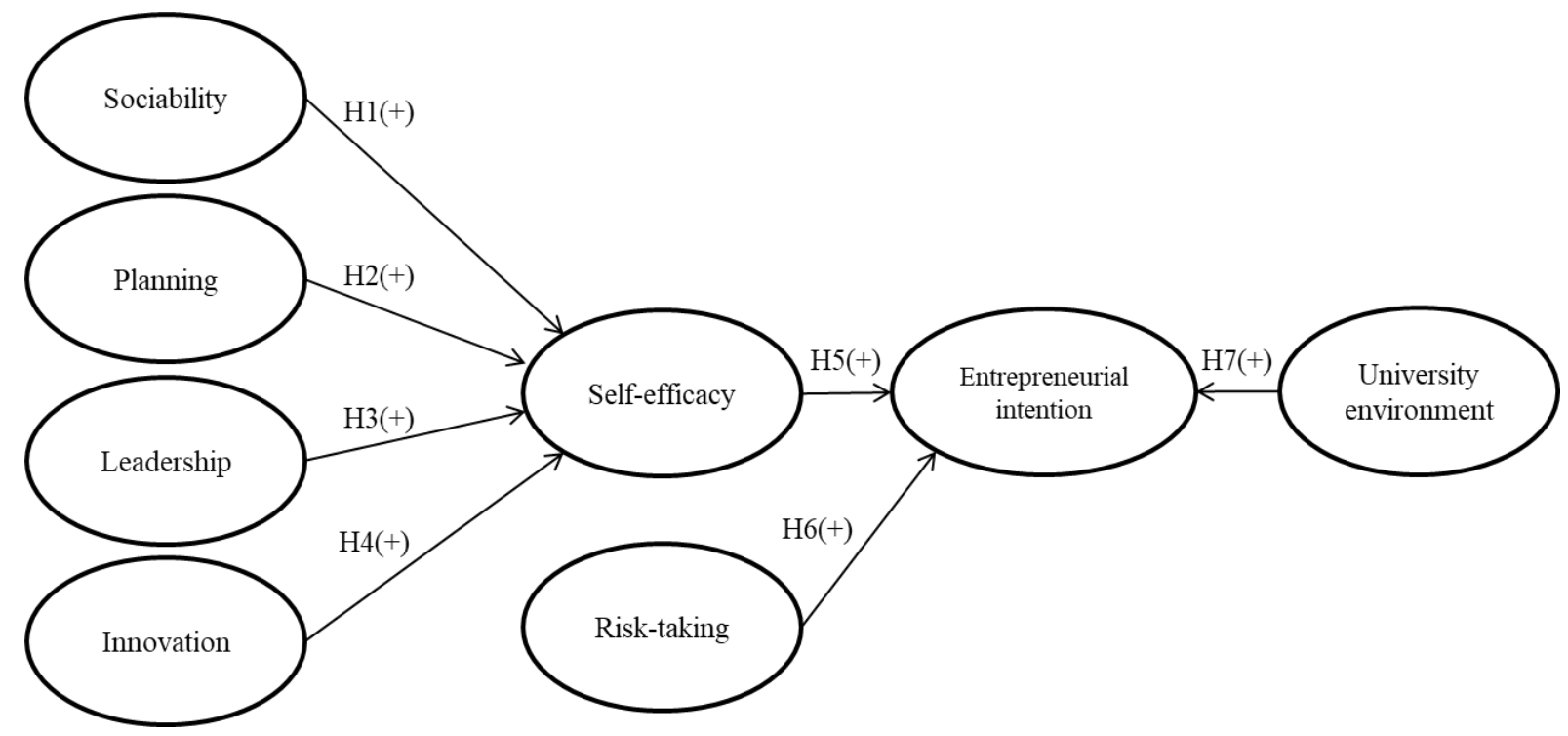

Figure 1. Conceptual Model of Research

The conceptual model was based on the relationship between self-efficacy and entrepreneurial intention (Chen et al., 1998; Piperopoulos \& Dimov, 2015; Pittaway et al., 2010; Robinson \& Sexton, 1994; Zellweger et al., 2011), on risk-taking as a predictor of entrepreneurial intention (Douglas \& Shepherd, 2002; Zhang, Wang, \& Owen, 2015), and on the university environment influencing entrepreneurial intention (Chen et al., 1998; Saeed, Yousafzai, Yani-De-Soriano, \& Muffatto, 2015; Souitaris, Zerbinati, \& Al-laham, 2007; Turker \& Selcuk, 2009).

Some indicators (sociability, planning, leadership, innovation, self-efficacy, and risk-taking) used in the questionnaire and for the preparation of the conceptual model were based on the research by Schmidt and Bohnenberger (2009) and Rocha and Freitas (2014). The questions regarding entrepreneurial intention were based and adapted from Liñán and Chen (2009) and Saeed et al. (2009). The construct of the university environment had as its main references the studies by Schwarz, Wdowiak, Almer-Jarz, and Breitenecker (2009) and Saeed et al. (2015), but some indicators were developed by the authors. 
Market specialists and academics in entrepreneurship were consulted for formulation of the hypotheses and elaboration of the model (Figure 1) and questions. Table 2 presents a description of the study's hypotheses.

Table 2

Study's Hypotheses

\begin{tabular}{cl}
\hline Hypotheses & Description \\
\hline H1 & Sociability positively influences self-efficacy. \\
H2 & Planning ability positively influences self-efficacy. \\
H3 & Leadership ability positively influences self-efficacy. \\
H4 & Innovation ability positively influences self-efficacy. \\
H5 & Self-efficacy positively influences the entrepreneurial intention. \\
H6 & Risk-taking positively influences the entrepreneurial intention. \\
H7 & The university environment positively influences entrepreneurial intention. \\
\hline
\end{tabular}

\section{Methodological Aspects}

The research was developed through quantitative methodology, with the use of multivariate data analysis. According to the suggestions by Hair, Hult, Ringle, and Sarstedt (2017), in which the goals are prediction and explanation of the constructs presented and the method provides a common point between path modeling and confirmatory factor analysis, we opted for the use of Partial Least Squares-Structural Equation Modeling (PLS-SEM). The model developed for research presents reflective and formative indicators, which is another reason to use PLS-SEM (Chin \& Newsted, 1999; Hair, Hult, Ringle, \& Sarstedt, 2017). We conducted a single cross-section survey, which seeks, among other objectives, to identify opinions of specific groups and distribution of the phenomenon in the population (Pinsonneault \& Kraemer, 1993).

To assess the face validity of the questionnaire, a pre-test was conducted with three types of people, according to the Forza's suggestion (2002): five potential respondents (Unicamp students); six academic specialists in entrepreneurship and three academic specialists in structural equation models; and five market specialists (entrepreneurship experts). The criteria used for the selection of academic specialists was at least five years of research in the field and publications in well-known journals. The criteria for the selection of market specialists were respondents having opened at least one company, experience in business management, and interest in the topic. The interviews were conducted to assess the validity of the assertions (Netemeyer, Bearden, \& Sharma, 2003).

The suggestions regarding this pre-test brought about some changes in the questionnaire, especially in the constructs of university environment, entrepreneurial intention, planning, and risktaking. The specialists helped in the validation and construction of new indicators, in order to measure the construct in a better way. Table 5 presents all the indicators and the references used to develop them. Another pre-test was conducted with a group of 110 respondents prior to the application of the questionnaire to the final sample, in order to validate the questionnaire and the constructs. The number of respondents should be at least ten for each item, and the study has eight items, so the number of respondents is adequate to this analysis (Everitt, 1975). With these answers, we conducted an exploratory analysis of the indicators by a correlation study among the items and corrected item-total correlations (CITC), which measures the correlation among items of the same factor, determining to which extent indicators like that share the same meaning (Churchill, 1979). Simsion (2007) recommends the elimination of items with CITC values below 0.30 . No indicator was eliminated by this criterion. 
This exploratory phase was necessary because not all scales were adapted from previous studies. Some scales, although based on other authors' ideas, had to be developed for this study, for example the university environment scale.

Next, an exploratory factor analysis was performed to identify whether the indicators have correlation among latent variables (factors). The method chosen to determine the factors was Principal Component Analysis with the oblique rotation method. It is recommended that the load factor of each indicator achieves a value higher than 0.70 (Hair, Black, Babin, Anderson, \& Tatham, 2009). In addition, it is expected that there will be difference of factorial load higher than 0.20 in adjacent constructs and that the commonality of each indicator has a value higher than 0.50 .

After completing exploratory factor analysis, indicators of the constructs leadership and innovation were removed due to failures in the divergent validation or reduced commonality. However, excluding these bookmarks did not compromise the recommendation by Werts, Linn, and Jöreskog (1974) advocating the maintenance of at least three items per construct so that there are satisfactory degrees of freedom for the factor analysis execution, as well as verifying the unidimensionality of constructs.

The Bartlett's sphericity test was also conducted with a null significance value in conjunction with calculation of the measure of adequacy of the sample Kaiser-Mayer-Olkin test, whose index was equal to 0.806 , values considered satisfactory for further analysis (Hair et al., 2009).

Cronbach's alpha was analyzed to verify the internal consistency of constructs. For exploratory studies, values between 0.60 and 0.70 are considered acceptable (Hair et al., 2017; Nunally \& Berstein, 1994;). In Table 3, we present the compared results of the reliability analysis of the indicators during the process of scales refinement.

Table 3

Reliability Analysis and Item-Total Correlations of Constructs

\begin{tabular}{lccccc}
\hline Constructs & $\begin{array}{c}\text { Cronbach's } \\
\text { alpha (before } \\
\text { adjustments) }\end{array}$ & $\begin{array}{c}\text { Cronbach's } \\
\text { alpha (after } \\
\text { adjustments) }\end{array}$ & $\begin{array}{c}\text { Number of } \\
\text { items }\end{array}$ & $\begin{array}{c}\text { CITC (before } \\
\text { adjustments) }\end{array}$ & $\begin{array}{c}\text { CITC (after } \\
\text { adjustments) }\end{array}$ \\
\hline Self-efficacy & 0.819 & 0.819 & 4 & $0.518-0.750$ & $0.518-0.750$ \\
Risk-taking & 0.796 & 0.785 & 4 & $0.526-0.684$ & $0.573-0.668$ \\
Innovation & 0.667 & 0.636 & 3 & $0.393-0.525$ & $0.398-0.514$ \\
Leadership & 0.726 & 0.747 & 3 & $0.349-0.641$ & $0.531-0.644$ \\
Planning & 0.736 & 0.736 & 4 & $0.463-0.600$ & $0.463-0.600$ \\
Sociability & 0.707 & 0.662 & 4 & $0.466-0.532$ & $0.481-0.512$ \\
$\begin{array}{l}\text { Entrepreneurial } \\
\text { intention }\end{array}$ & 0.854 & 0.854 & 5 & $0.571-0.765$ & $0.571-0.765$ \\
\hline
\end{tabular}

Exclusion of indicators for composing the final measuring instrument did not compromise the values of Cronbach's alpha, which remained satisfactory, apart from an improvement in item-total correlations of the indicators contained in the instrument of collection for the final sample. Results obtained ensure the use of the measuring instrument adjusted for data collection in the final sample.

Table 4 presents the indicators of the measuring instrument, indicating the questions that have been excluded and the references. 
Table 4

\section{Scale Indicators of the Measuring Instrument}

\begin{tabular}{|c|c|c|}
\hline Indicator & Question & Reference \\
\hline LE1 & I am often chosen as a leader in school or professional activities. & \multirow{3}{*}{$\begin{array}{l}\text { Schmidt and Bohnenberger } \\
\text { (2009); Rocha and Freitas } \\
\text { (2014). }\end{array}$} \\
\hline LE2 & People respect my opinion. (excluded) & \\
\hline LE3 & $\begin{array}{l}\text { I can convince people to overcome conflicts and work as a team to } \\
\text { achieve a particular result. }\end{array}$ & \\
\hline LE4 & $\begin{array}{l}\text { I am able to encourage people to perform tasks for which they are } \\
\text { unmotivated. }\end{array}$ & $\begin{array}{l}\text { Adapted from Schmidt and } \\
\text { Bohnenberger (2009). }\end{array}$ \\
\hline PL1 & I always plan everything I do very carefully & $\begin{array}{l}\text { Schmidt and Bohnenberger } \\
\text { (2009); Rocha and Freitas } \\
\text { (2014). }\end{array}$ \\
\hline PL2 & To achieve my goals, I detail all the steps to be followed. & $\begin{array}{l}\text { Adapted from Rocha and } \\
\text { Freitas (2014). }\end{array}$ \\
\hline PL3 & I know I can set my short, medium and long-term goals. & \multirow[t]{2}{*}{ Developed by the authors. } \\
\hline PL4 & I like to set goals and targets to feel challenged. & \\
\hline IN1 & I prefer a job full of novelty instead a routine activity. & \multirow{2}{*}{$\begin{array}{l}\text { Schmidt and Bohnenberger } \\
\text { (2009); Rocha and Freitas } \\
(2014) \text {. }\end{array}$} \\
\hline IN2 & I like changing my way of work whenever possible. (excluded) & \\
\hline IN3 & $\begin{array}{l}\text { I like improving the conventional and correct way of activities, not } \\
\text { strictly following steps. }\end{array}$ & \multirow[t]{2}{*}{$\begin{array}{l}\text { Adapted from Schmidt and } \\
\text { Bohnenberger (2009). }\end{array}$} \\
\hline IN4 & I bet on creativity while elaborating projects/activities. & \\
\hline RT1 & $\begin{array}{l}\text { I would assume a long-term debt, believing in the advantages that a } \\
\text { business opportunity would bring me. }\end{array}$ & \multirow{2}{*}{$\begin{array}{l}\text { Schmidt and Bohnenberger } \\
\text { (2009); Rocha and Freitas } \\
(2014) \text {. }\end{array}$} \\
\hline RT2 & I admit taking risks in exchange for possible benefits. & \\
\hline RT3 & My decisions are not predominantly based on my comfort zone. & \multirow[t]{2}{*}{ Developed by the authors. } \\
\hline RT4 & $\begin{array}{l}\text { I believe that getting involved in situations of higher risk will create } \\
\text { results of great impact. }\end{array}$ & \\
\hline SO1 & $\begin{array}{l}\text { The social contacts that I have are very important for my personal } \\
\text { life. }\end{array}$ & \multirow{2}{*}{$\begin{array}{l}\text { Schmidt and Bohnenberger } \\
\text { (2009); Rocha and Freitas } \\
\text { (2014). }\end{array}$} \\
\hline $\mathrm{SO} 2$ & $\begin{array}{l}\text { I know several people who could assist me professionally, if I needed } \\
\text { it. }\end{array}$ & \\
\hline $\mathrm{SO} 3$ & I relate very easily with other people. & $\begin{array}{l}\text { Schmidt and Bohnenberger } \\
(2009) \text {. }\end{array}$ \\
\hline $\mathrm{SO} 4$ & I try to maintain constant contact with people in my network. & Developed by the authors. \\
\hline SE1 & I think I have skills to detect business opportunities in the market. & \multirow[t]{3}{*}{ Rocha and Freitas (2014). } \\
\hline SE3 & Professionally, I consider myself much more persistent than others. & \\
\hline SE4 & I always find creative solutions to the problems I encounter. & \\
\hline SE2 & I perform my duties properly, respecting the deadlines set. & Developed by the authors. \\
\hline
\end{tabular}


Table 4 (continued)

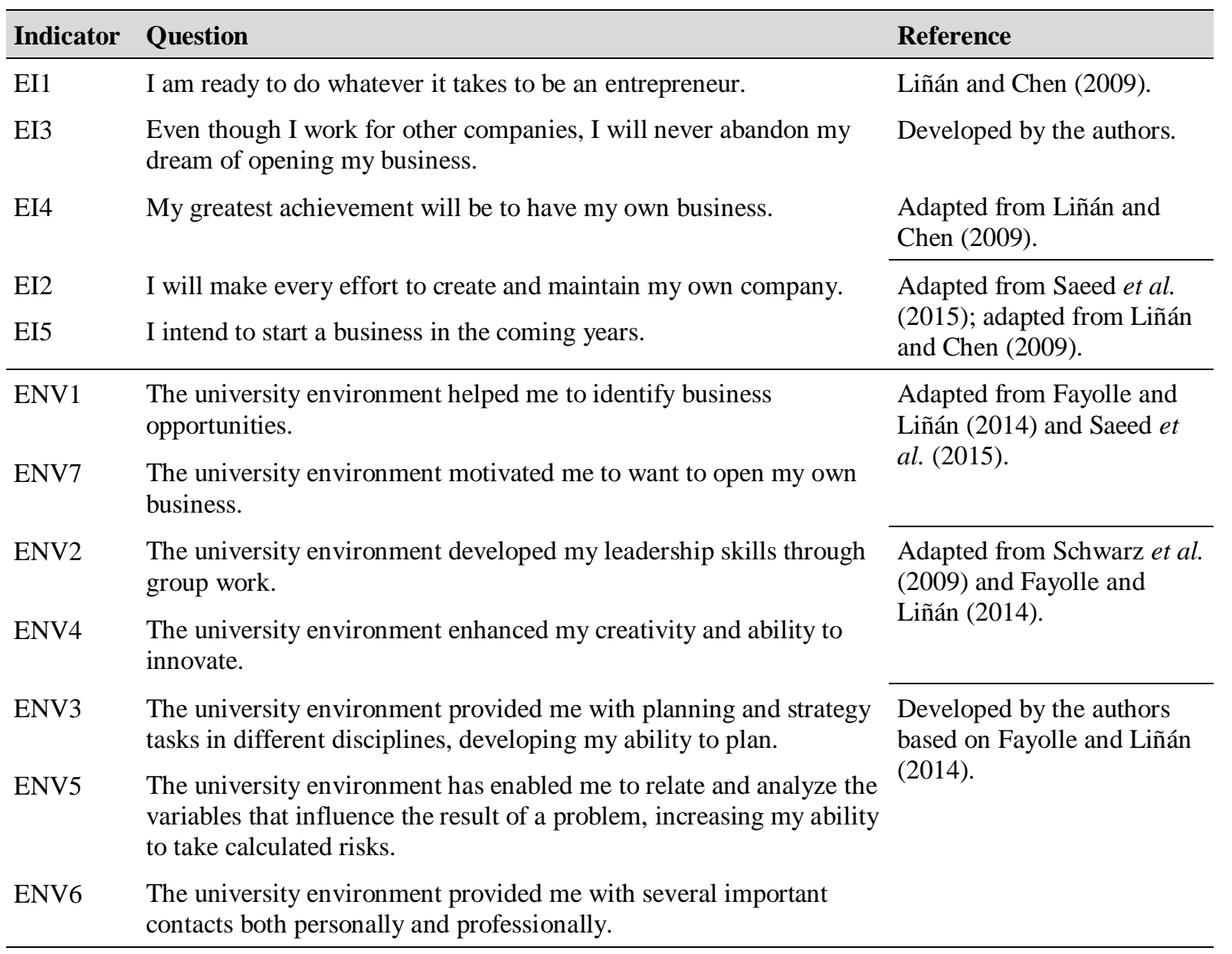

Note. Leadership - LE; Planning - PL; Innovation - IN; Risk-taking - RT; Sociability - SO; Self-efficacy - SE; Entrepreneurial intention - EI; University environment - ENV.

To evaluate the sample size and statistical power of the analysis, an analysis with the G*Power 3.1 software (Faul, Erdfelder, Buchner, \& Lang, 2009) was conducted and based on the recommendations by Chin and Newsted (1999), Cohen (1988), and Hair et al. (2017). Considering four predictors, a significance level of $5 \%$, a statistical power of 0.8 , and an average effect size $\left(\mathrm{f}^{2}=0.15\right.$, which is equivalent to $\mathrm{r}^{2}=13 \%$ ), the minimum size of the sample required is 85 . As the final sample used comprised 287 people, it is suitable for estimation by Partial Least Squares Path Modeling (PLSPM). The analyses a posteriori (post hoc) for the sample obtained indicate that: (a) any $\mathrm{r}^{2}$ higher than $4.22 \%$ would be detected as significant, keeping the power of 0.8 and the significance level of $5 \%$; and (b) to the average effect size the power is of 0.999 , which is well above the value 0.8 , recommended by Chin and Newsted (1999).

Data collection for this survey was conducted through a questionnaire with seven-point Likerttype scales. The questionnaire was approved by the Ethics Committee of the university, through the submission to Plataforma Brasil. An online version of the questionnaire was sent to the institutional email of all final-year students of engineering and business undergraduate programs, accompanied by a cover letter. The email was sent on behalf of the research team with the permission of the institution's director. At first, the research link was sent to all students who were part of the sample. After two weeks, the link was resubmitted only to students who had not responded. This process was performed four times when the response rate was very low. Questionnaires that took more than 30 minutes to answer were discarded. The questions were in random order in the research link. 
The total of validated responses was 287 from a possible 360, and 73 responses were discarded because they were incomplete. Data collection lasted 90 days and was conducted in the first semester of 2016.

To minimize the possible effects of common method bias (CMB), some suggestions from Podsakoff, Mackenzie, and Podsakoff (2012) were used, such as preserving the anonymity of respondents to avoid acquiescence and social desirability, and keeping the items simple and the survey short to increase the probability of the student responding accurately and not in a stylistic mode. Despite this, it is not possible to ensure that there is no bias, as this would only be possible with the use of objective measures for the dependent variable.

SmartPLS software 3.0 M3 (Ringle, Wende, \& Becker, 2015) was used for the calculations and validations of the statistical tests, developed through the multivariate analysis technique of structural equation modeling.

\section{Description and Results Analysis}

The model presents reflective indicators (sociability, planning, leadership, innovation, selfefficacy, risk-taking, and entrepreneurial intention) and a formative indicator (university environment). Thus, each indicator will be evaluated in accordance with the appropriate criteria.

\section{Evaluation of formative measurement models}

The criteria for evaluation of formative measurement models are: convergent validity, multicollinearity analysis, and significance and relevance (Hair et al., 2017).

Convergent validity was determined through redundancy analysis. This analysis was done through the correlation of variables of the formative construct with a global measure of the indicator. The construct was modeled as the independent variable and the global measure as the dependent variable. It is necessary that the value of the path coefficient is greater than 0.80 so that the formative construct has convergent validity (Hair et al., 2017). In the case of the university environment construct, the value was from 0.845 , providing support for convergent validity.

To test the collinearity of indicators, the values of Variance Inflation Factor (VIF) for variables of the formative construct should be lower than five (Hair et al., 2017), and all values were within the established range.

The bootstrapping technique in SmartPLS was used to analyze significance and relevance. According to the t-statistics of outer weights, the indicators ENV4 and ENV7 are significant, but the variables ENV1 and ENV2 are not. However, Hair et al. (2017) recommend analyzing the outer loadings too. In the t-statistics analysis of the outer loadings, all variables are significant, thus the recommendation is to maintain the variables.

\section{Evaluation of reflective measurement models}

Criteria for evaluating reflective measurement models, according to Hair et al. (2017) are: internal consistency (composite reliability); reliability of the indicator; convergent validity (average variance extracted); and discriminant validity.

The convergent and discriminant validities were assessed at the level of indicators and latent variables. Almost all indicators presented factorial loads in their latent variables superior to 0.70 (convergent validity), and low factorial loads in the other latent variables (discriminant validity), indicating reasonable convergent and discriminant validity (Chin, 1998). 
Another indicator used for convergent validation of the model is the value of the Average Variance Extracted (AVE), which as a criterion for validation must submit a value higher than 0.5 (Hair, Ringle, \& Sarstedt, 2011).

To evaluate the measurement model, besides examination of the loading for each indicator, a main measure used is composite reliability of each construct (Hair et al., 2017). Composite reliability describes the degree to which the indicators represent the latent construct in common. A commonly used benchmark for acceptable reliability is 0.70 .

Internal consistency was verified to analyze the convergent validity. A high value of internal consistency in the construct indicates that all variables represent the same latent construct. Internal consistency is evaluated through Cronbach's alpha, which varied from 0 to 1 , with high values indicating a higher level of consistency. For exploratory studies, values between 0.60 and 0.70 are considered acceptable; but for studies at more advanced stages, values between 0.70 and 0.90 are considered satisfactory (Hair et al., 2017; Nunally \& Berstein, 1994).

The evaluation of discriminant validity between the constructs is also given by calculating the square root of the AVE from constructs. This value must be higher than the correlation between latent variables (Fornell \& Larcker, 1981).

All the mentioned indicators are presented in Table 5 and are within established parameters (Chin, 1998; Hair et al., 2011; Hair et al., 2017; Nunally \& Berstein, 1994).

The value presented diagonally, in bold, is the square root of the AVE.

Table 5

Summary of the Evaluation of Measurement Models

\begin{tabular}{|c|c|c|c|c|c|c|c|c|}
\hline Constructs & SE & RT & IN & LE & PL & SO & ENV & EI \\
\hline SE & 0.706 & & & & & & & \\
\hline RT & 0.386 & 0.779 & & & & & & \\
\hline IN & 0.449 & 0.519 & 0.750 & & & & & \\
\hline LE & 0.519 & 0.236 & 0.397 & 0.742 & & & & \\
\hline PL & 0.441 & 0.155 & 0.234 & 0.407 & 0.779 & & & \\
\hline SO & 0.295 & 0.382 & 0.380 & 0.438 & 0.206 & 0.750 & & \\
\hline ENV & 0.258 & 0.408 & 0.247 & 0.177 & 0.206 & 0.144 & Formative & \\
\hline EI & 0.343 & 0.500 & 0.432 & 0.224 & 0.291 & 0.226 & 0.571 & 0.852 \\
\hline Cronbach's alpha & 0.661 & 0.787 & 0.750 & 0.728 & 0.786 & 0.743 & Formative & 0.904 \\
\hline Composite reliability & 0.793 & 0.860 & 0.837 & 0.830 & 0.860 & 0.837 & Formative & 0.929 \\
\hline $\begin{array}{l}\text { Variance average } \\
\text { extracted (AVE) }\end{array}$ & 0.500 & 0.608 & 0.563 & 0.551 & 0.607 & 0.563 & Formative & 0.725 \\
\hline
\end{tabular}

\section{Evaluation of the structural model}

Before evaluating the structural model, it is necessary to evaluate the collinearity of the structural model. The values of tolerance and VIF for each subpart of the structural model were analyzed to evaluate collinearity. The values are within those established by Hair et al. (2017), being a tolerance above 0.2 and a VIF below 5 .

The bootstrapping technique was used to analyze the significance of indicators (Efron \& Tibshirani, 1998). The use of a bootstrapping technique to analyze the significance of loadings obtained 
for the observable variables is not only based on an estimation of model, but also calculates estimates of parameters and their confidence intervals based on multiple estimates (Hair et al., 2009; Hair et al., 2017).

The Student's t-test analyzes the hypothesis that the coefficients of correlation are equal to zero. If the results of this test indicate values higher than 1.96, the hypothesis is rejected, and the correlation is significant (Efron \& Tibshirani, 1998; Hair et al., 2017).

Table 6 presents the values of coefficients between the constructs and their respective Student's t-tests. The values were estimated by a bootstrapping technique.

All values of the relationships presented Student t-values higher than 1.96 (significance level = $5 \%$ ), except sociability with self-efficacy, which did not support this hypothesis (H1).

Table 6

Coefficients of the Structural Model - Between Constructs

\begin{tabular}{lllll}
\hline Indicators & Average & Standard error & t-value & p-value \\
\hline Sociability-> Self-efficacy & 0.010 & 0.059 & 0.121 & 0.903 \\
\hline Planning-> Self-efficacy & 0.252 & 0.060 & 4.181 & 0.000 \\
\hline Leadership-> Self-efficacy & 0.310 & 0.063 & 4.914 & 0.000 \\
\hline Innovation-> Self-efficacy & 0.266 & 0.057 & 4.643 & 0.000 \\
\hline Self-efficacy-> Entrepreneurial intention & 0.274 & 0.050 & 5.593 & 0.000 \\
\hline Risk-taking-> Entrepreneurial intention & 0.124 & 0.046 & 2.768 & 0.006 \\
\hline Environment-> Entrepreneurial intention & 0.437 & 0.053 & 8.062 & 0.000 \\
\hline
\end{tabular}

To evaluate the coefficient of determination $\left(\mathrm{r}^{2}\right)$, the studies by Cohen (1988) and Faul, Erdfelder, Lang, and Buchner (2007) were used, which determined that $\mathrm{f}^{2}$ values equal to $0.02,0.15$, and 0.35 are considered, respectively, as small, medium, and large effects. These $\mathrm{f}^{2}$ values represent values of $\mathrm{r}^{2}$ equal to $2 \%, 13 \%$, and $25 \%$, respectively.

According to the responses, the construct self-efficacy presented a $\mathrm{r}^{2}$ of 0.400 , considered high, the construct entrepreneurial intention presented $\mathrm{a}^{2}$ of 0.424 , also considered high.

The model resulting from the research is presented in Figure 2. The numbers in the arrows indicate the factor loadings. 


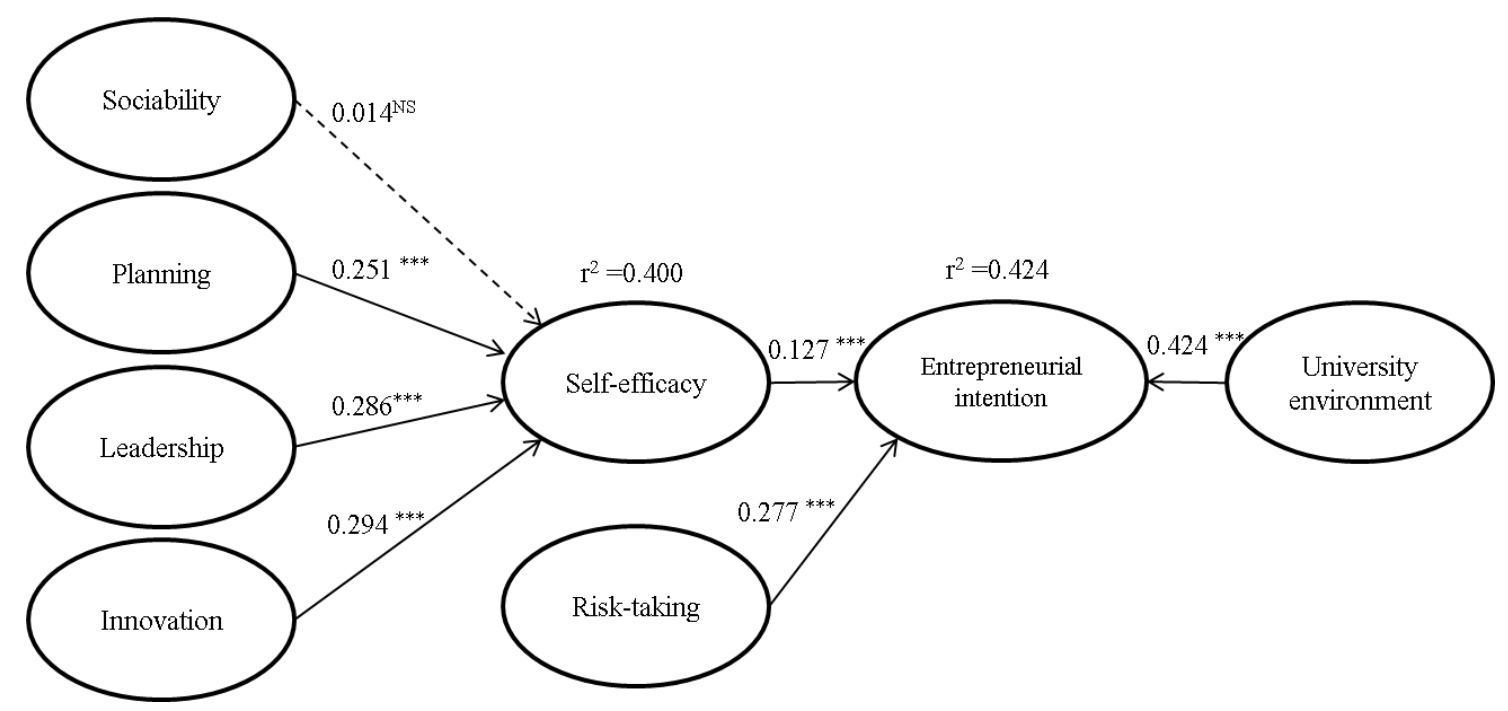

Figure 2. Model Resulting from Research NS $=$ not significant; $*=$ significant at $5 \% ; * *=$ significant at $1 \% ; * * *=$ significant at $0.1 \%$.

Besides evaluating the magnitude of $\mathrm{r}^{2}$ values as a criterion of predictive accuracy, it is necessary to evaluate the value $\mathrm{Q}^{2}$, which is an indicator of the model's predictive relevance. According to Hair $e t$ al. (2017, p. 178): "The $\mathrm{Q}^{2}$ value is obtained by using the blindfolding procedure for a certain omission distance. Blindfolding is an iterative process that repeats until each data point has been omitted and the model reestimated". Values of $\mathrm{Q}^{2}$ higher than zero indicate the predictive relevance of the path model. In the case of this study, the values are considered adequate (Hair et al., 2017).

The synthesis of the study hypotheses tests (Table 7) were obtained with validations derived from the structural model.

Table 7

Synthesis of the Study Hypotheses Tests

\begin{tabular}{cll}
\hline Hypotheses & Description & Result \\
\hline H1 & Sociability positively influences self-efficacy. & NOT CONFIRMED \\
H2 & Planning ability positively influences self-efficacy. & CONFIRMED \\
H3 & Leadership ability positively influences self-efficacy. & CONFIRMED \\
H4 & Innovation ability positively influences self-efficacy. & CONFIRMED \\
H5 & Self-efficacy positively influences entrepreneurial intention. & CONFIRMED \\
H6 & Risk-taking positively influences entrepreneurial intention. & CONFIRMED \\
H7 & The university environment positively influences entrepreneurial intention. & CONFIRMED \\
\hline
\end{tabular}

The results related to the hypotheses tested in this research reinforce the academic literature on self-efficacy (Chen et al., 1998) regarding innovation, planning, risk-taking, and also on entrepreneurial intentions (Fayolle \& Liñán, 2014) as being influenced by the context, institution, and educational process provided by the university environment, something that had not yet been tested. In addition, it must be said that the research brought something beyond what had already been dealt with in the literature, in that leadership was confirmed as a valid construct for self-efficacy as opposed to sociability. 


\section{Conclusions}

Aiming to create and validate a model to explain the effects of entrepreneurial characteristics and the university environment on entrepreneurial intention, the research was able to meet the goal, as it presented a consistent model, with high explanatory value of the latent variables entrepreneurial intention and self-efficacy.

In relation to the study results, entrepreneurial intention is positively influenced by self-efficacy, risk-taking, and university environment, confirming previous similar investigations (Chen et al., 1998; Fayolle \& Liñán, 2014).

The university environment is the construct that most influences entrepreneurial intention. This way, when the student's assessment is positive in relation to the university environment; i.e. when the university environment provides for the development of attitudinal characteristics of students, this increases entrepreneurial intention.

This result should be highlighted, as Fayolle and Liñán (2014) argued that in the context of research on entrepreneurial intention, it was necessary to investigate entrepreneurial education and the relationship with entrepreneurial intention. This research sought to investigate something that the literature on entrepreneurial intention had not investigated; the final result shows that there is a positive relationship between the context, the institution, the entrepreneurial education and students' entrepreneurial intentions.

The second most influential factor in entrepreneurial intention is risk-taking. Thus, the greater the student's predisposition and security to take risks, managing to relate and analyze better the variables that can influence the results correctly, the greater their entrepreneurial intention will be.

The third factor is self-efficacy, so the more the student feels able to run his/her own business and manage physical and human resources, the greater the entrepreneurial intention.

According to the proposed model, self-efficacy was explained by planning, leadership, and innovation. On the other hand, the construct sociability did not provide evidence of influencing selfefficacy.

Innovation is the construct that most influences self-efficacy. Thus, when students consider themselves able to link ideas, facts, needs, and market demands in a creative way, the greater their selfefficacy will be.

Leadership is the second factor that most influences self-efficacy. The greater the influence that the student has on other people, the greater their self-efficacy will be.

Finally, planning is the third largest factor of influence on the self-efficacy construct. In this way, the more the students prepare for the future, the greater their cognitive estimate on their mobilization ability.

Sociability is the degree of use of the social network to support the student's professional activity. In the studies of Rocha and Freitas (2014), sociability also showed no significant changes in the entrepreneurial profile. The fact that sociability has not presented evidence of influencing self-efficacy may be due to the fact that the students are still forming their network, and still do not clearly identify the possibilities of partnerships. Or perhaps because they are young students, people belonging to their networks are as young as those who tend not to contribute to professional and entrepreneurial selfefficacy. Another reason could be some failure in the development of the model or the survey questions.

The results corroborate those of Schmidt and Bohnenberger (2009), regarding factor analysis. However, the mentioned authors did not validate the model with entrepreneurial intention and university environment. 
The study sought to collaborate complementary reflections with entrepreneurship studies conducted in Brazil, providing a tool for evaluation of entrepreneurial intention that contemplates the entrepreneurial profile and the university environment. The results may serve as support for the improvement of university environments in the context of teaching, research, and outreach, aimed at entrepreneurship.

There are implications for educational institutions and also for companies interested in young entrepreneurs. In the case of universities, it is suggested to invest in a type of education in which research and its extensions are aligned around entrepreneurship training, as this will increase students' entrepreneurial intent. For businesses, research indicates that investing in activities that encourage entrepreneurial research as well as extension activities that complement classrooms; for example, the promotion of college awards related to solving real market problems is important. The presented theoretical model was designed to include research and its extensions in the understanding of education as well as the enterprising intention of students. It is recommended that this be considered in future research, since the teaching of entrepreneurship must be analyzed in combination with research and extension activities.

Some of the study limitations need to be highlighted and are as follows. Only one educational institution was analyzed and only two programs were contemplated. There may be measurement errors due to imprecision in the measurement of the actual values by applying the online questionnaire. The survey was conducted with a single cross-section; cognitive limitation of researchers and expert groups to develop the theoretical model and to construct some indicators may be involved. The statistical technique did not consider some new tests presented by Hair, Sarstedt, Ringle and Gudergan (2018), for example: Heterotrait-Monotrait Ratio (HTMT), Goodness-of-Fit measures in PLS-SEM (Dijkstra \& Henseler, 2015), Normed Fit Index (NFI) or Bentler-Bonett index Standardized Root Mean Square Residual (SRMR), Observed and Unobserved Heterogeneity, Importance-Performance Map among others.

Based on the limitations, some possibilities for future research are as follows: conduct qualitative studies to understand why significant relations occur; conduct a second order PLS-SEM to verify which variables from the university environment should be considered to understand entrepreneurial intention and to form the university environment; carry out longitudinal research; validate the theoretical model with more than one focus group; test the difference between groups (examples: age, program, and gender); conduct research related to the mediating role of self-efficacy in the development of entrepreneurial intention.

\section{References}

Ajzen, I. (1991). The theory of planned behavior. Organizational Behavior and Human Decision Processes, 50(2), 179-211. http://dx.doi:10.1016/0749-5978(91)90020-T

Ajzen, I., \& Fishbein, M. (1980). Understanding attitudes and predicting social behavior. Englewood Cliffs, NJ: Prentice-Hall.

Audretsch, D. B., Grilo, I., \& Thurik, A. R. (2011). Globalization, entrepreneurship, and the region. In M. Fritsch (Ed.), Handbook of research on entrepreneurship (pp. 11-32). Cheltenham: Edward Elgar.

Autio, E., Keeley, R. H., Klofsten, M., Parker, G. G. C., \& Hay, M. (2001). Entrepreneurial intent among students in Scandinavia and in the USA. Enterprise and Innovation Management Studies, 2(2), 145-160. http://dx.doi.org/10.1080/14632440110094632 
Autio, E., Keeley, R. H., Klofsten M., \& Ulfstedt, T. (1997). Entrepreneurial intention among students: Testing an intention model in Asia, Scandinavia and USA. Proceedings of the Frontiers of Entrepreneurship Research, Babson College, Babson Park, MA.

Bandura, A. (1986). The explanatory and predictive scope of self-efficacy theory. Journal of Clinical and Social Psychology, 4(3), 359-373. http://dx.doi.org/10.1521/jscp.1986.4.3.359

Bignotti, A., \& Le Roux, I. (2016). Unravelling the conundrum of entrepreneurial intentions, entrepreneurship education, and entrepreneurial characteristics. Acta Commercii, 16(1), 1-10. http://dx.doi.org/10.4102/ac.v16i1.352

Boyles, T. (2012). 21st century knowledge, skills, and abilities and entrepreneurial competence: A model for undergraduate entrepreneurship education. Journal of Entrepreneurship Education, $15(1), 41-55$.

Brenner, O. C., Pringle, C. D., \& Greenhaus J. H. (1991). Perceived fulfilment of organizational employment versus entrepreneurship: Work values and career intentions of business college graduates. Journal of Small Business Management, 29(3), 62-74.

Carland, J. W., Hoy, F., \& Carland, J. A. C. (1988). "Who is an entrepreneur?" Is a question worth asking. American Journal of Small Business, 12(4), 33-39. http://dx.doi.org/10.1177/104225878801200402

Chen, C. C., Greene, P. G., \& Crick, A. (1998). Does entrepreneurial self-efficacy distinguish entrepreneurs from managers? Journal of Business Venturing, 13(4), 295-316. http://dx.doi.org/10.1016/S0883-9026(97)00029-3

Chin, W. W. (1998). The partial least squares approach to structural equation modeling. In G. A. Marcoulides (Ed.), Modern methods for business research (pp. 295-358). Mahwah, NJ: Lawrence Erlbaum.

Chin, W. W., \& Newsted, P. R. (1999). Structural equation modeling analysis with small samples using partial least squares. In R. H. Hoyle (Ed.), Statistical strategies for small sample research (pp. 307-341). Thousand Oaks, CA: Sage Publications.

Churchill, G. A., Jr. (1979). A paradigm for developing better measures of marketing constructs. Journal of Marketing Research, 16(1), 64-73. http://dx.doi.org/10.2307/3150876

Cohen, J. (1988). Statistical power analysis for the behavioral sciences (2nd ed.). Hillsdale, NJ: Erlbaum.

Degen, R. J. (1989). O empreendedor: Fundamentos de iniciativa empresarial. São Paulo: McGramHill.

Degen, R. J. (2009). O empreendedor: Empreender como opção de carreira. São Paulo: Pearson Prentice Hall.

Dijkstra, T. K., \& Henseler, J. (2015). Consistent and asymptotically normal PLS estimators for linear structural equations. Computational Statistics \& Data Analysis, 81(1), 10-23. http://dx.doi.org/10.1016/j.csda.2014.07.008

Douglas, E. J., \& Shepherd, D. A. (2002). Self-employment as a career choice: Attitudes, entrepreneurial intentions, and utility maximization. Entrepreneurship Theory and Practice, 26(3), 81-90. Retrieved from http://dx.doi.org/10.4337/9781783479801.00025 https://eprints.qut.edu.au/5527/1/5527_1.pdf.

Drucker, P. F. (1986). Inovação e espírito empreendedor. São Paulo: Pioneira. 
Efron, B., \& Tibshirani, R. J. (1998). An introduction to the bootstrap. Boca Raton, London and New York, Washington, DC: Chapman \& Hall / CRC Press.

Everitt, B. S. (1975). Multivariate analysis: The need for data, and other problems. British Journal of Psychiatry, 126(1), 237-240. http://dx.doi.org/10.1192/bjp.126.3.237

Faul, F., Erdfelder, E., Buchner, A., \& Lang, A.-G. (2009). Statistical power analyses using G*Power 3.1: Tests for correlation and regression analyses. Behavior Research Methods, 41(4), 1149-1160. http://dx.doi.org/10.3758/BRM.41.4.1149

Faul, F., Erdfelder, E., Lang, A.-G., \& Buchner, A. (2007). G*Power 3: A flexible statistical power analysis program for the social, behavioral, and biomedical sciences. Behavior Research Methods, 39(2), 175-191. http://dx.doi.org/10.3758/BF03193146

Fayolle, A., \& Gailly, B. (2015). The impact of entrepreneurship education on entrepreneurial attitudes and intention: Hysteresis and persistence. Journal of Small Business Management, 53(1), 75-93. http://dx.doi.org/10.1111/jsbm.12065

Fayolle, A., \& Liñán, F. (2014). The future of research on entrepreneurial intentions. Journal of Business Research, 67(5), 663-666. http://dx.doi.org/10.1016/j.jbusres.2013.11.024

Filion, L. J. (2000). Empreendedorismo e gerenciamento: processos distintos, porém complementares. Revista de Administração da USP, 7(3), 2-7. http://dx.doi.org/10.1590/S003475902000000300013

Fleming, P. (1994). The role of structured interventions in shaping graduate entrepreneurship. IBAR: Journal of Irish Business and Administrative Research, 15, 146-157.

Fornell, C., \& Larcker, D. F. (1981). Evaluating structural equation models with unobservable variables and measurement error. Journal of Marketing Research, 18(1), 39-50. http://dx.doi.org/10.2307/3150980

Forza, C. (2002). Survey research in operations management: A process-based perspective. International Journal of Operations \& Production Management, 22(2), 152-194. http://dx.doi.org/10.1108/01443570210414310

Gatewood, E. J., Shaver, K. G., Powers, J. B., \& Gartner, W. B. (2002). Entrepreneurial expectancy, task effort and performance. Entrepreneurship Theory and Practice, 27(2), 187-206. http://dx.doi.org/10.1111/1540-8520.00006

Giovanela, A., Gouveia, A. B. C. T. de, Frâncio, S., \& Dalfano, O. (2010). As características da disciplina de empreendedorismo em Instituições de Ensino Superior do Estado de Santa Catarina. Revista Gestão Universitária na América Latina, 3(1), 69-84. http://dx.doi.org/10.5007/19834535.2010v3n1p69

Godoy, A. S., \& Antonello, C. S. (2009). Competências individuais adquiridas durante os anos de graduação de alunos do curso de administração de empresas. Revista de Ciências da Administração, 11(23), 11-29. http://dx.doi.org/10.5007/2175-8077.2009v11n23p157

Guerrero, M., Urbano, D., \& Gajón, E. (2014). The internal pathways that condition university entrepreneurship in Latin America: An institutional approach. Advances in the Study of Entrepreneurship, Innovation \& Economic Growth, 24, 65-87.

Gupta, V., \& Fernandez, C. (2009). Cross-cultural similarities and differences in characteristics attributed to entrepreneurs: A three-nation study. Journal of Leadership \& Organizational Studies, 15(3), 304-318. http://dx.doi.org/10.1177/1548051808326036 
Hair, J. F., Black, W. C., Babin, B. J., Anderson, R. E., \& Tatham, R. L. (2009). Análise multivariada de dados (6a ed.). Porto Alegre: Bookman.

Hair, J. F., Hult, G. T. M., Ringle, C. M., \& Sarstedt, M. (2017). A primer on partial least squares structural equation modeling (PLS-SEM) (2nd ed.). Thousand Oaks, CA: Sage.

Hair, J. F., Ringle, C. M., \& Sarstedt, M. (2011). PLS-SEM: Indeed a silver bullet. Journal of Marketing Theory and Practice, 19(2), 139-151. http://dx.doi.org/10.2753/MTP1069-6679190202

Hair, J. F., Sarstedt, M., Ringle, C. M., \& Gudergan, S. P. (2018). Advanced issues in partial least squares structural equation modeling (PLS-SEM). Thousand Oaks, CA: Sage.

Henrique, D. C., \& Cunha, S. K. (2008). Práticas didático-pedagógicas no ensino de empreendedorismo em cursos de graduação e pós-graduação nacionais e internacionais. Revista de Administração Mackenzie, 9(5), 112-136. http://dx.doi.org/10.1590/S1678-69712008000500006

Hindle, K., \& Cutting, N. (2002). Can applied entrepreneurship education enhance job satisfaction and financial performance? An empirical investigation in the Australian pharmacy profession. Journal of Small Business Management, 40(2), 162-167. http://dx.doi.org/10.1111/1540$627 X .00048$

Honig, B. (2004). Entrepreneurship education: Toward a model of contingency-based business planning. Academy of Management Learning and Education, 3(3), 258-273. http://dx.doi.org/10.5465/AMLE.2004.14242112

Iizuka, E. S., \& Moraes, G. H. S. M. (2014). Análise do potencial e perfil empreendedor do estudante de administração e o ambiente universitário: Reflexões para instituições de ensino. Administração: $\quad$ Ensino \& $\quad$ Pesquisa, http://dx.doi.org/10.13058/raep.2014.v15n3.16

Ilander, G. P. B. (2010). The use of feature films to promote entrepreneurship. International Journal Information and Operation Management Education, 3(3), 284-302. http://dx.doi.org/10.1504/IJIOME.2010.033551

Izique, C. (2016). Inova Unicamp rastreia empreendedores ex-alunos. Agência FAPESP. Retrieved from http://agencia.fapesp.br/inova_unicamp_rastreia_empreendedores_entre_exalunos/23957/

Jamieson, I. (1984). Schools and enterprise. In A. G. Watts \& P. Moran (Eds.), Education for enterprise (pp. 19-27). Cambridge, MA: Careers Research and Advisory Centre (CRAC).

Johannisson, B. (1991). University Training for Entrepreneurship: A Swedish approach. $\begin{array}{llll}\text { Entrepreneurship and Regional } & \text { Development, } & \text { 3(1), } & \text {. }\end{array}$ http://dx.doi.org/10.1080/08985629100000005

Knotts, T. L. (2011). The SBDC in the classroom: Providing experiential learning opportunities at different entrepreneurial stages. Journal of Entrepreneurship Education, 14(1), 25-38.

Koh, H. C. (1996). Testing hypotheses of entrepreneurial characteristics a study of Hong Kong MBA $\begin{array}{lllll}\text { Students. Journal of Managerial Psychology, 11(3), } & \text { 12-25. }\end{array}$ http://dx.doi.org/10.1108/02683949610113566

Kolvereid, L. (1996). Organizational employment versus self-employment: Reasons for career choice intentions. Entrepreneurship Theory and Practice, 20(3), 23-31. http://dx.doi.org/10.1177/104225879602000302

Kolvereid, L., \& Moen, O. (1997). Entrepreneurship among business graduates: Does a major in entrepreneurship make a difference? Journal of European Industrial Training, 21(4), 154-160. http://dx.doi.org/10.1108/03090599710171404 
Kuratko, D. F. (2005). The emergence of entrepreneurship education: Development, trends, and challenges. Entrepreneurship Theory and Practice, 29(5), 577-598. http://dx.doi.org/10.1111/j.1540-6520.2005.00099.x

Krueger, N. F. (1993). The impact of prior entrepreneurial exposure on perceptions of new venture feasibility and desirability. Entrepreneurship: Theory and Practice, 18(1), 5-21. http://dx.doi.org/10.1177/104225879301800101

Krueger, N., \& Brazeal, D. (1994). Entrepreneurial potential and potential entrepreneurs. Entrepreneurship Theory and Practice, 18(3), 91-104.

Lautenschläger, A., \& Haase, H. (2011). The myth of entrepreneurship education: Seven arguments against teaching business creation at universities. Journal of Entrepreneurship Education, 14(1), 147-161.

Lima, E. O., Lopes, R. M., Nassif, V. M. J., \& Silva, D. (2015). Opportunities to improve entrepreneurship education; contributions considering Brazilian challenge. Journal of Small Business Management, 53(4), 1033-1051. http://dx.doi.org/10.1111/jsbm.12110

Liñán, F., \& Chen, Y. (2009). Development and cross-cultural application of a specific instrument to measure entrepreneurial intentions. Entrepreneurship Theory and Practice, 33(3), 593-617. http://dx.doi.org/10.1111/j.1540-6520.2009.00318.x

Liñán, F., \& Fayolle, A. (2015). A systematic literature review on entrepreneurial intentions: Citation, thematic analyses, and research agenda. International Entrepreneurship and Management Journal, 11(4), 907-933. http://dx.doi.org/10.1007/s11365-015-0356-5

Liñán, F., Rodríguez-Cohard, J., \& Rueda-Cantuche, J. (2011). Factors affecting entrepreneurial intention levels: A role for education. The International Entrepreneurship and Management Journal, 7(2), 195-218. http://dx.doi.org/10.5539/ass.v11n4p180

Luthje, C., \& Franke, N. (2003). The making of an entrepreneur: Testing a model of entrepreneurial intent among engineering students at MIT. $R \& D$ Managemen, 33(2), 135-146. http://dx.doi.org/10.1111/1467-9310.00288

Markman, G. D., \& Baron, R. A. (2003). Person-entrepreneurship fit: Why some people are more successful as entrepreneurs than others. Human Resource Management Review, 13(2), 281-301. http://dx.doi.org/10.1016/S1053-4822(03)00018-4

McClelland, D. C. (1961). The achieving society. Princeton: Van Nostrand.

Netemeyer, R. G., Bearden, W. O., \& Sharma, S. (2003). Scaling procedures: Issues and applications. Thousand Oaks, CA: Sage Publications.

Nunally, J. C., \& Bernstein, I. (1994). Psychometric theory. New York: McGraw-Hill.

Peterman, N. E., \& Kennedy, J. (2003). Enterprise education: Influencing students' perceptions of entrepreneurship. Entrepreneurship Theory and Practice, 28(2), 129-144. http://dx.doi.org/10.1046/j.1540-6520.2003.00035.x

Peterson, R. T., \& Limbu, Y. (2010). Student characteristics and perspectives in entrepreneurship courses: A profile. Journal of Entrepreneurship Eduation, 13(1), 65-83.

Pinsonneault, A., \& Kraemer, K. (1993). Survey research methodology in management information systems: As assessment. Journal of Management Information Systems, 10(2), 75-105. http://dx.doi.org/10.1080/07421222.1993.11518001 
Piperopoulos, P., \& Dimov, D. (2015). Burst bubbles or build steam? Entrepreneurship education, entrepreneurial self-efficacy, and entrepreneurial intentions. Journal of Small Business Management, 53(4), 970-985. http://dx.doi.org/10.1111/jsbm.12116

Pittaway, L., Rodriguez-Falcon, E., Aiyegbayo, O., \& King, A. (2010). The role of entrepreneurship clubs and societies in entrepreneurial learning. International Small Business Journal, 29(1), 3757. http://dx.doi.org/10.1177/0266242610369876

Podsakoff, P. M., MacKenzie, S. B., \& Podsakoff, N. P. (2012). Sources of method bias in social science research and recommendations on how to control it. Annual Review of Psychology, 63, 539-569. http://dx.doi.org/10.1146/annurev-psych-120710-100452

Quacquarelli Symonds. (2016). QS world university rankings 2016-2017. Elsevier. Retrieved from https://www.topuniversities.com/student-info/university-news/qs-world-university-rankings20162017-global-press-release

Ringle, C. M., Wende, S., \& Becker, J. (2015). SmartPLS 3. Bönningstedt: SmartPLS. Retrieved from https://www.smartpls.com/

Robinson, P. B., \& Sexton, E. A. (1994). The effect of education and experience on self-employment success. Journal of Business Venturing, 9(2), 141-156. Retrieved from https://EconPapers.repec.org/RePEc:eee:jbvent:v:9:y:1994:i:2:p:141-156

Rocha, E. L. C., \& Freitas, A. A. F. (2014). Avaliação do ensino de empreendedorismo entre estudantes universitários por meio do perfil empreendedor. Revista de Administração Contemporânea, 18(4), 465-486. Recuperado de http://www.scielo.br/pdf/rac/v18n4/1415-6555-rac-18-0400465.pdf. http://dx.doi.org/10.1590/1982-7849rac20141512

Ruskovaara, E., Pihkala, T., Rytkölä, T., \& Seikkula-Leino, J. (2010). Studying teachers' teaching methods and working approaches in entrepreneurship education. Proceedings of the ESU Conference, Tartu, Estonia, 22.

Saeed, S., Yousafzai, S. Y., Yani-De-Soriano, M., \& Muffatto, M. (2015). The role of perceived university support in the formation of students' entrepreneurial intention. Journal of Small Business Management, 53(4), 1127-1145. http://dx.doi.org/10.1111/jsbm.12090

Sarri, K., \& Trihopoulou, A. (2005). Female entrepreneurs' personal characteristics and motivation: A review of the Greek situation. Women in Management Review, 20(1), 24-36. http://dx.doi.org/10.1108/09649420510579559

Schmidt, S., \& Bohnenberger, M. C. (2009). Perfil empreendedor e desempenho organizacional. Revista de Administração Contemporânea, 13(3), 450-467. Recuperado de http://www.scielo.br/pdf/rac/v13n3/v13n3a07.pdf. $\quad$ http://dx.doi.org/10.1590/S141565552009000300007

Schmidt, J. S., Soper. J. C., \& Facca, T. M. (2012). Creativity in the entrepreneurship classroom. Journal of Entrepreneurship Education, 15(1), 123-131.

Segal, G., Borgia, D., \& Schoenfeld, J. (2005). The motivation to become an entrepreneur. International Journal of Entrepreneurial Behaviour \& Research, 11(1), 42-57. http://dx.doi.org/10.1108/13552550510580834

Simsion, G. (2007). Data modeling: Theory and practice. Melbourne: Technics Publications.

Souitaris, V., Zerbinati, S., \& Al-Laham, A. (2007). Do entrepreneurship programmes raise entrepreneurial intention of science and engineering students? The effect of learning, inspiration and resources. Journal of Business Venturing, 22(4), 566-591. http://dx.doi.org/10.1016/j.jbusvent.2006.05.002 
Schwarz, E. J., Wdowiak, M. A., Almer-Jarz, D. A., \& Breitenecker, R. J. (2009). The effects of attitudes and perceived environment conditions on students' entrepreneurial intent. An Austrian $\begin{array}{llll}\text { perspective. } \quad \text { Education }+ \text { Training, } & \text { 51(4), }\end{array}$ http://dx.doi.org/10.1108/00400910910964566

Times Higher Education (2017, September 7). World university ranking 2018. Retrieved from https://digital.timeshighereducation.com/TimesHigherEducationWorldUniversityRankings2018/ offline/download.pdf

Tkachev, A., \& Kolvereid, L. (1999). Self-employment intentions among Russian students. Entrepreneurship and Regional Development, 11(3), 269-280. Retrieved from https://EconPapers.repec.org/RePEc:taf:entreg:v:11:y:1999:i:3:p:269-280

Turan, M., \& Kara, A. (2007). An exploratory study of characteristics and attributes of Turkish entrepreneurs: A cross-country comparison to Irish entrepreneurs. Journal of International Entrepreneurship, 5(1), 25-46. http://dx.doi.org/10.1007/s10843-007-0014-2

Turker, D., \& Selcuk, S. S. (2009). Which factors affect entrepreneurial intention of university students? Journal of European Industrial Trainin, 33(2), 142-159. http://dx.doi.org/10.1108/03090590910939049

Wang, C. K., \& Wong, P. K. (2004). Entrepreneurial interest of university students in Singapore. Technovation, 24(2), 163-172. http://dx.doi.org/10.1016/S0166-4972(02)00016-0

Werts, C., Linn, R., \& Jöreskog, K. (1974). Intraclass reliability estimates: Testing structural assumptions. Educational and Psychological Measurement, 34(1), 25-33. http://dx.doi.org/10.1177/001316447403400104

Whetten, D. A. (1989). What constitutes a theoretical contribution? Academy of Management Review, 14(4), 490-495. http://dx.doi.org/10.5465/AMR.1989.4308371

Zellweger, T., Sieger, P., \& Halter, F. (2011). Should I stay or should I go?: Career choice intentions of students with family business background. Journal of Business Venturing, 26(5), 365-377. http://dx.doi.org/10.1016/j.jbusvent.2010.04.001

Zhang, P. L., Wang, D. D., \& Owen C. L. (2015). A study of entrepreneurial intention of university students. Entrepreneurship Research Journal, 5(1), 1-22. Retrieved from https://EconPapers.repec.org/RePEc:bpj:erjour:v:5:y:2015:i:1:p:22:n:2.

https://doi.org/10.1515/erj-2014-0004

\section{Authors' Profiles}

Gustavo Hermínio Salati Marcondes de Moraes

Rua Pedro Zaccaria, 1300, Jardim Santa Luiza, 13484-350, Limeira, SP, Brasil. E-mail address: gustavo.salati@fca.unicamp.br. http://orcid.org/0000-0001-5238-0314

Edson Sadao Iizuka

Rua Tamandaré, 688, Liberdade, 01525-000, São Paulo, SP, Brasil. E-mail address: esadao@ fei.edu.br

Matheus Pedro

Rua Pedro Zaccaria, 1300, Jardim Santa Luiza, 13484-350, Limeira, SP, Brasil. E-mail address: matpedro999@ gmail.com 